\title{
Morgagni-Stewart-Morel syndrome
}

INSERM

\section{Source}

INSERM. (1999). Orphanet: an online rare disease and orphan drug data base. MorgagniStewart-Morel syndrome. ORPHA:77296

Morgagni-Stewart-Morel syndrome is characterised by thickening of the inner table of the frontal bone, sometimes associated with obesity and hypertrichosis. It mainly affects women over 35 years of age. The prevalence and clinical significance of hyperostosis frontalis interna is unknown. Transmission is either X-linked or autosomal dominant. 